\title{
The Significance of Body and Resurrection in the Roman Catholic Order of Christian Funerals
}

\author{
by
}

\section{Bruce T. Morrill*}

\section{Introduction: Faith's Assent to the Body}

Christianity's healing response to death's bitter sting is faith in the bodily resurrection of Jesus. To speak of human death as well as the resurrection of the body is to engage mystery, indeed two distinct, powerful, yet related mysteries in Christian life. For believers there is both the phenomenon common to all people, the definitive limit-situation that is death, and the call to shape one's entire vision for life around the belief that God raised the executed Jesus bodily from the dead, that is, faith in the paschal mystery:

In the face of death, the Church confidently proclaims that God has created each person for eternal life and that Jesus, the Son of God, by his death and resurrection, has broken the chains of sin and death that bound humanity. Christ "achieved his task of redeeming humanity and giving perfect glory to God principally by the paschal mystery of his blessed passion, resurrection from the dead, and glorious ascension."'1

The confidence in God's redemptive will for humanity articulated in the General Introduction of the current Roman Catholic Order of Christian Funerals is a recovery of the evangelical faith native to the early centuries of Christianity yet often muted in the subsequent history of Western Christendom and beyond. ${ }^{2}$ It is, as one might expect, a complicated history. My basic point for this article is that the content of biblical faith, divine revelation, comes only as an invitation within the socialcultural milieus of particular times and places. ${ }^{3}$ Christian tradition has never healed

\footnotetext{
*The Rev. Dr. Bruce T. Morrill, S.J., is on the faculty of the Department of Theology at Boston College, Massachusetts, USA. He may be contacted morrilb@bc.edu.

${ }^{1}$ International Committee on English in the Liturgy, Order of Christian Funerals, 1989, no. 1. Hereafter, OCF. This passage quotes from Vatican Council II, Sacrosanctum concilium (SC) 5.

${ }^{2}$ For a fine survey of the history, see Richard Rutherford, The Death of a Christian: The Order of Christian Funerals, rev. ed. (Collegeville, Minn.: Liturgical Press, 1990) 3-112, especially 28, 59-60, and 86.

${ }^{3}$ See Louis-Marie Chauvet, The Sacraments: The Word of God at the Mercy of the Body (Collegeville, Minn.: Liturgical Press, 2001) 3-9.
} 
the human fracture of death through a kind of textual positivism, as if one could assert propositions alone, everybody would comprehendingly assent, and the disconcerting challenges of death - variably sudden, protracted, tragic, violent, peaceful, yet always provoking loss, grief, and the like-would simply be settled. On the contrary, people wrestle with images, customs, traditions, and so forth, pulling them together at a given time to bring some meaning, some consolation, some hope, to the crisis of death.

Richard Rutherford sheds light on the promise and challenge the church always faces in service to the dead and bereaved: "The fact of death is the greatest human threat to faith in the paschal mystery. There is nothing in death that even hints at the viability of such a paschal faith." 4 In order to understand Christians' faith in the resurrection of the body, therefore, attention to theoretical arguments alone cannot prove an adequate theology. At the outset of her study of the doctrine of resurrection and its praxis from early through medieval Christianity, Carolyn Walker Bynum makes the following observation: "I assume that the technical arguments of philosophical and theological treatises frequently betray the problems they cannot solvesocial and psychological as well as intellectual problems-in the limiting cases, examples, and metaphors they use and in the ways they distort or misread conventional tropes and images." 5 Philosophical argument and theological treatise cannot exhaust or even always recognize what Christians in a given time and place mean by resurrection of the body because the human body itself, as we learn from Louis-Marie Chauvet, is not reducible to simple description, concise explanation, ready comprehension.

Chauvet, building on the work of Martin Heidegger, articulates the complex phenomenon of the human person as an "I-body," a subject whose corporality is a "triple body" comprised of culture, tradition, and nature. ${ }^{6}$ Avoiding rhetoric of embodiment that might surreptitiously isolate spirit from body, making the latter a mere vehicle of the former, Chauvet wisely speaks of the person-body to indicate that each of us does not have a body but, rather, is a body, a body at once physical, socio-cultural, and traditional. The body is natural in its physicality, sharing in the rhythms and forces of the cosmos. While there is a "givenness" to this participation in the physical universe, the way in which people develop meaning in relation to the cosmos comes nevertheless through the mediation of culture and tradition.

${ }^{4}$ Rutherford, The Death of a Christian, 122.

${ }^{5}$ Carolyn Walker Bynum, The Resurrection of the Body in Western Christianity 200-1336 (New York: Columbia University Press, 1995) xvi (emphasis in the original); see also 7.

${ }^{6}$ Louis-Marie Chauvet, Symbol and Sacrament: A Sacramental Reinterpretation of Christian Existence, trans. Patrick Madigan and Madeleine Beaumont (Collegeville, Minn.: Liturgical Press, 1995) 146-52. 
Each human subject as body constructs meaning for one's life, uniquely according to one's own desires, through a myriad of socially shared symbols. Thus, the body is the fundamental functioning symbol, the "arch-symbol," of human experience. ${ }^{7}$ The cultural dimension of bodily subjectivity entails the customs, values, and symbols practiced by members of a social body, constantly changing, whether gradually or abruptly, due to various historical forces. In contrast, the traditional dimension of human corporality gives authority to seemingly changeless ${ }^{8}$ symbols, narratives, rituals, and creedal beliefs connecting people with a more or less mythic past and the transcendent dimension of reality. In actual lived practice, the three bodily dimensions of human existence-natural, cultural, traditional - do not function, of course, independently but, rather, mutually influence each other, with one or the other often taking priority in certain circumstances.

Chauvet's body theory is crucial for what I hope to accomplish in this article, namely, an articulation of some of the promise and challenges for pastoral service to the dead, the bereaved, and the wider community evident in the practice of the Order of Christian Funerals in late-modern contexts. The particular tradition within the body of Christianity I am engaging is contemporary Roman Catholicism, and the primary social situation, the church in North America. I nonetheless trust that the global and porous characteristics of late modernity and the ecumenical history behind the reformed rites of Roman Catholicism will allow a range of readers to profit from this investigation into the saving (in the primordial sense of healing) force of the gospel in contemporary Christians' real-symbolic engagements with death.

\section{Different Approaches to the Body in Question}

Some fifteen years of pastoral experience leads me to proffer a few general types of approach to the person-body of the deceased that, upon some reflection, bear different practical theologies of death and the Christian funeral. A growing phenomenon among American Catholics can be characterized as the person-body viewed, celebrated, and cremated. American families-Catholic, Christian, and otherwisefor more than a century have typically been availing themselves of the professional services of the undertaker (also called the funeral director), who embalms and cosmetically prepares the corpse for viewing in the funeral home. The basic ritual

${ }^{7}$ Ibid., 151.

${ }^{8}$ This perception of tradition as seemingly changeless by its practitioners (what anthropologists call the emic perspective) belies the fact that traditions are always subtly changing. Catherine Bell argues that the effectiveness of traditions depends on their ability to engage "collective images of the past," drawing on the authority of precedent and a perception of consensus that nonetheless allows for a "degree of latent conflict" in forms of "mere compliance, quiet evasion, or idiosyncratic rejection" (Ritual Theory, Ritual Practice [New York: Oxford University Press, 1992] 122-23). 
in this context is "the last look" at the deceased, a forum for final direct contact with the person-body (understood by many to be an interpersonal exchange with the deceased, "saying goodbye"), paying respects to the family, and meeting common friends in the body's presence. Personal and retrospective dimensions characterize the overall ritual process, often along with a dogged assertion of happiness as the prescribed tone for the memorializing: "celebrating a life." This manner of memorializing, while not necessarily at total odds with the Order of Christian Funerals, ${ }^{9}$ nonetheless can often assert a cheerful retrospective focus that banishes expressions of separation and loss. Ritual emphasis on happy remembrance can fail individuals' (if not communal bodies') needs to grieve. Those emotional needs are often met, if at all, through private therapeutic services. While the value of the latter must not be gainsaid, still the problematic question persists as to whether this leaves Christian liturgy trapped in a truncated social role of merely paralleling social practices ("celebrations of life") already going on, a squandering of treasures within the tradition that might better serve human need. ${ }^{10}$

A second approach, often to some extent in reactionary relationship to the first, is that of the person-body of the deceased placed before the altar of priestly mediation. I have in mind here American Catholic funeral masses I have observed in which the priest and other liturgical ministers, to varying degrees, dispense with elements of the official Roman funeral rite, such as the reception of the body in the church entrance or the final commendation, to such an extent as to reduce the funeral to a simple mass for the dead. ${ }^{11}$ Such an approach would seem to betray a clericalism contradictory to fundamental principles of the Second Vatican Council's doctrine of the liturgy, namely, the active participation of all in the paschal

9 "Christians celebrate the funeral rites to offer worship, praise, and thanksgiving to God for the gift of a life, which has now been returned to God, the author of life and the hope of the just. The Mass, the memorial of Christ's death and resurrection, is the principal celebration of the Christian funeral"' (OCF, no. 5).

${ }^{10}$ My reflections along these lines are highly influenced by Johann Baptist Metz's ongoing critique of the predominant practical, pastoral theology in North Atlantic parishes, his anxiousness over the church's ministry merely mouthing what society already knows and, thus, offering nothing substantial in the face of suffering. Metz, for example, argues that in our postmodern propensity for myths that are supposed to console us we have lost the "biblical meaning of consolation . . . a hope [that] resists the attempt to expel a sense for what is absent from our wisdom about ourselves" (A Passion for God: The Mystical-Political Dimension of Christianity, trans. J. Matthew Ashley [New York: Paulist Press, 1998] 160).

1 I have witnessed dispensing with the greeting of the grieving family, the sprinkling and covering of the casket with a white pall (symbols of baptism), the incensing of gospel book, eucharistic gifts, assembly, and finally the deceased in the coffin - all elements designed to enable participants to connect somatically this situation of death with the story of salvation. In contrast, a Mass for the Dead is a matter of certain collect prayers and suggested readings in the course of a typical mass. 
mystery and the multiple ways Christ is present in the rites (assembly, presider, word, and sacramental symbols). ${ }^{12}$ Elimination of the reception of the body and final commendation effectively erases the deceased as a subject, as a person-body, as a sacramental sign to the assembled of his/her and their baptismal right and duty to share in the liturgical actualization of their membership in Christ's body. With that erasure comes the discarding of the sacramental expression of the mission each and every baptized member is called to realize in their lives, the irrelevance of the content of scripture as revealing God's word for this specific moment and people, the loss of a "sure and certain hope" shaped by faith in Christ's resurrection. In place of that celebration of the paschal mystery is the "default religion" 13 of the priest confecting the body and blood of Christ before the assembled, an action apparently conferring dignity upon those present at the Holy Sacrifice, the deceased in the coffin and the congregation in the pews. In such a socialreligious division of ritual labor, the cleric's dominant (often to the point of exclusive) role in the real work of the mass to the neglect of his presiding over a liturgical assembly leaves everybody else to make of the event what they will. The music director may provide one standard selection of four hymns performed with a solo vocalist. Those attending are most likely either consoled to witness the special mass, satisfied that this death has been marked with proper seriousness and dignity, or put off by the religious content and official behavior. Others are left to infuse the ceremony with supplemental content, whether material (e.g., "celebrating a life" commemorative pamphlets) or within the sanctuary of one's own thoughts.

British theologian and religious historian Douglas Davies observes that the complex contemporary "circumstances of death and funerals" (i.e., minimal knowledge of or interest in religious doctrines, life in pluralistic society, etc.) dispose people to "what might be called a cultural "default position" " of following the standard path set by their religious and funerary professionals. ${ }^{14}$ Davies reports that while late-modern families of the deceased remain committed to the "default position" of the given religion's ritual, often only because it is the easier way "to ensure a satisfactory performance," they are increasingly assertive in their requests for personal readings or music "as markers of individuality set within the traditional framework." ${ }^{15}$ Christian pastors in North Atlantic societies are, in turn, increasingly willing to shift from their traditions' symbolic framing of the deceased as a brother or sister becoming part of the communion of saints to "the individuality

\footnotetext{
12 See SC 7, 14.

${ }^{13}$ See Douglas J. Davies, A Brief History of Death (Malden: Blackwell, 2005) 57-58.

14 Ibid., 58.

15 Ibid., 58-59.
} 
of each person - as individual in death as in life." 16 American Catholic bishops have recently been pushing back against this trend, even as many local priests find themselves incapable of providing solid theological and liturgical reasons for the official prohibition of eulogies at the funeral mass, the inclusion of songs like "Danny Boy," and the insertion of non-biblical readings. ${ }^{17}$ The problem, I would argue, is due in no small part to the clergy's unfamiliarity with the practical, spiritual theology of the reformed rites of the church (in this case, the Order of Christian Funerals). Unable to form and guide their people in the biblically powerful, pastorally flexible scope of the rites, priests end up asserting their judgments concerning funeral practices on the basis of their clerical authority alone, even as that argument from power continues to lose force among baby-boomer, millennial, and younger Catholics. ${ }^{18}$

The Order of Christian Funerals, then, comprises a third approach to the deceased person as a member of the body of Christ in communion with the assembly's celebration of the paschal mystery. Citing 1 Corinthians 12:26, "If one member suffers in the body of Christ which is the Church, all the members suffer with that member," the General Introduction identifies the entire community, lay and ordained, as responsible for the "ministry of consolation to those who have suffered the loss of one whom they love." 19 The theological heart of this approach is "rooted in that hope that comes from faith in the saving death and resurrection of the Lord Jesus Christ." 20 The point here is to recognize the rite's insistence-both in the theology of the General Introduction and the ritual's words and symbols-upon praising and thanking God for the life of the deceased while also ministering to the sorrow of the family and friends. "The responsibility for the ministry of consolation rests with the believing community," whose "faith . . . in the resurrection

${ }^{16}$ Ibid., 60 .

17 "The issue of what is decorous and what is not at Roman Catholic funerals flares up periodically around the [USA]. A handful of ... dioceses ... forbid eulogies at funerals, said Sister Maryanne Walsh, a spokeswoman for the United States Conference of Catholic Bishops, and some others place limits on them. Bishops and pastors have occasionally discouraged the playing of popular songs like 'Danny Boy' or 'Wind Beneath My Wings.' " The laity's response has been widely negative: "Funeral directors in the archdiocese [of Newark, New Jersey] said that most funerals there include eulogies during the Mass, and that the decree had aroused widespread resentment... A funeral director who spoke on the condition of anonymity said that one group of mourners was heard cursing in the church parking lot last week after a eulogist was forbidden to speak" (Daniel J. Wakin, "Archbishop of Newark Bans Eulogies at Masses," New York Times, January 23, 2003).

${ }^{18}$ For evidence of the declining importance of religious practices and authority of church leaders and teachings, including statistical data and narrative interpretations, see: "Survey of U.S. Catholics: American Catholics from John Paul II to Benedict XVI," National Catholic Reporter, September 30, 2005.

${ }^{19}$ OCF, no. 8 .

${ }^{20}$ Ibid. 
of the dead brings support and strength to those who suffer the loss of those whom they love." 21 This duty the faithful execute by both sharing their particular ministerial gifts throughout the three stages of the funeral rites and "assisting [the mourners] with some of the routine tasks of daily living," such as meal preparation, transportation, child or elder care, etc. ${ }^{22}$ Thus, the faith community's liturgical contributions and practical "acts of kindness" together affect a reintegration of both the deceased into the symbolic reality of Christ's body -in death as in life ${ }^{23}$ and all the participants in the funeral process-family, friends, community, pastoral ministers- with the deceased into a singular celebration of the paschal mystery.

The integrated vision of the Order of Christian Funerals provides the members of the Church with an ideal that, as I noted in my introduction, is only realized to varying degrees in practice. To use Chauvet's terminology, the three bodies of human subjectivity-natural/cosmic, social/cultural, and traditional — would appear to be vying with one another for the upper hand in people's efforts to construct meaning in the face of death. This pastoral reality, however, should be a cause of neither surprise nor alarm, for it is but one example of what Chauvet means by asserting that the Word of God's continual submission to the ambiguities of the body is the kenotic hallmark of our salvation in Christ. Chauvet argues for the patience and solicitude pastoral ministers should thereby practice in responding to frequent requests for liturgical rites of passage from people either ignorant of or resistant to the traditional content and practice of the faith. ${ }^{24}$ Indeed, such a pastoral approach is a practical form that ministers' paschal faith as "the assent to a loss" takes. ${ }^{25}$

Such a complex reality warrants further analysis, which I shall undertake by aligning Chauvet's theory of the triple body with a threefold typology of memorializing the dead that Davies has gleaned from the contemporary Northern Atlantic social landscape. Building on cultural anthropologist Branislaw Malinowski's study of death, Davies proposes hope as always contextual, "related to lived architectural events and the allurement of place." 26 Places charged with social-traditional

$21 \mathrm{OCF}$, no. 9.

22 Ibid., no. 10.

23 See Rom 14:8.

24 See Chauvet, The Sacraments, 51-54, 173-200.

25 Ibid., 39. "In their significant materiality, the sacraments thus constitute an unavoidable stumbling block which forms a barrier to every imaginary claim to a direct connection, individual and interior, with Christ or to a gnostic-like, illuminist contact with him. ... They tell us that the faith has a body, that it adheres to our body. More than that, they tell us that to become a believer is to learn to consent, without resentment, to the corporality of the faith" (Chauvet, Symbol and Sacrament, 153 [emphasis in the original]).

${ }^{26}$ Davies, A Brief History of Death, 117. 
import allure people in their desire to flourish in the face of death. This recognition enables Davies to craft his typology of various burial practices: "When times change, through altered circumstance, dramatic events and the innovative creativity of individuals, new opportunities for allurement arise. In sociological terms new kinds of affinity develop between people and forms of memorial and hope." ${ }^{27}$ Herein lies an affinity as well between Davies' typology and Chauvet's fundamental sacramental theology: faith's content is attained only through the "triple body of culture, tradition, and nature," ${ }^{28}$ mutually impacting conditions for how people attain meaning in life (and death). In the next section I shall follow Davies' order for presenting three models of contemporary North Atlantic memorials to the dead, each of which has a particular way of locating hope that gives priority to one of Chauvet's three dimensions of human corporality. That analysis will lead, finally, to the healing power yet challenging content of faith in the resurrection of the body as the pivotal symbol at the juncture of culture and tradition in the current Christian ritualizing of death.

\section{Locating the Deceased: A Typology of Contemporary Hope for the Dead}

\section{Communal, Eschatological Hope: The Traditional Body}

Davies observes that peoples across times and cultures tend to integrate the dead into their worlds of meaning by reasserting the deceased's identity in relation to a new location in space and time: "Hope and place are inextricably aligned." 29 Traditional Christian hope lies in the eschatological fulfillment of "those ... who have died in Christ" (1 Cor 15:18), whom Christ "will raise . . up on the last day" (John 6:40). Beginning with the earliest generations, Christians buried their dead with reverence in expectation of their being raised "at the last trumpet," when Christ, "the first fruits of those who have died," will come "and the dead will be raised imperishable ... changed" to immortal bodies like that of him in whose name they were baptized ( 1 Cor 15: 20, 53, and see 29). That hope of immortality, while grounded in baptism, ancient Christians found assured through their sharing in the eucharist, the "bread of life" (John 6:35), leading to their association of the bodies of their dead with the eucharistic body of the church..$^{30}$ The early believers came to celebrate the eucharist on the graves or near the (symbolically decorated)

${ }^{27}$ Ibid., 116.

${ }^{28}$ Chauvet, Symbol and Sacrament, 150 (emphasis in the original).

29 Davies, A Brief History of Death, 117.

${ }^{30}$ See Robert Cabié, The Eucharist, The Church at Prayer, rev. ed., vol. 2, trans. Matthew O'Connell (Collegeville, Minn.: Liturgical Press, 1986) 38-39. See also Rutherford, The Death of a Christian, 6-9. 
sarcophagi of their beloved dead, with ensuing centuries bringing the building of churches on the burial sites of martyrs and saints. Vaults, tombs, and plots in the floors, altars, and graveyards of churches, as well as spaces in large cemeteries, eventually with sections consecrated by local churches, have comprised the traditional Christian locations of hope in the face of death. ${ }^{31}$ Hope in this case, Davies summarizes, is eternal in nature and eschatological in form, shaping a vision for not only the afterlife (eternal rest, perpetual light) but also "the drive to survive and flourish in this life too." 32

The Order of Christian Funerals carries out the Second Vatican Council's mandate that all rites be revised on the basis of sound tradition so that the Church's liturgy might function as a renewed source for the faith-lives of its members, ${ }^{33}$ in this case as they confront the hard reality of death. Ancient Christian tradition, Rutherford summarizes, understood death as believers' hopeful, confident going to Christ, communicated through such symbols as sharing in the "rest" of Abraham, the model of life based on faith in God's promise, and such iconography as the good shepherd, loaves and fishes, vine and branches. Patristic treatises disqualify the despairing displays of mourning (wailing, physical mutilation) typical in their contemporary societies as incongruous with Christian faith in Jesus' resurrection, teaching instead that the humanly understandable grief of bereavement was to find expression through singing psalms and hymns, contemplating biblical images, and especially offering prayers. Augustine taught that the church passes no judgment on the deceased but, rather, trusting in God's mercy, offers prayers, alms, and the eucharist for any and all the baptized who, except for the martyrs, surely die with some sin in need of forgiveness. Respect for the body of the deceased manifested faith in the redemption of human nature and hope in the resurrection of those justified in Christ. ${ }^{34}$ In the sixth century Pseudo-Dionysius explained that bringing the body into the church "symbolized one's place in everlasting life as a follower of Christ," while prayer "over the faithful dead for the forgiveness of sins and the reward of a place in the company of patriarchs [proclaimed] the promise of unending life to those who love God."35

${ }^{31}$ On the Carolingian origins and French linguistic roots of the cemetery, as well as the medieval development of the charnel house (ossuary), see Bynum, The Resurrection of the Body, 203-5, 212-13.

32 Davies, A Brief History of Death, 118.

33 See SC 3, 4.

34 See Rutherford, The Death of a Christian, 15-19. For a discussion of the complexity of Augustine's teaching about body, resurrection, and judgment, see Bynum, The Resurrection of the Body, 94-104.

${ }^{35}$ Rutherford, The Death of a Christian, 21-22. 
Beginning in the seventh century, however, confidence in God's mercy toward the faithful departed steadily ceded to fear of divine judgment; the hopeful going to sleep in Christ, to the dread of Christ the all-power judge. Gregory the Great and others took Augustine's teaching of prayer for the dead in an expiatory direction: "The prayer of the Church, they taught, brought about the liberation of the faithful dead from the purifying fire of expiation for $\sin$. Before long, this fire would become localized as 'purgatory' and the tradition of prayer for the release of the 'poor souls' its complement in popular piety." 36 The early eucharistic theology promising koinonia in the body of Christ at the heavenly banquet diminished; in a medieval church preoccupied with fear of death, the offering of mass functioned under an individualistic and atoning eschatology for languishing souls. The Requiem Mass, which began in the thirteenth century papal court, made its way into the mainstream, becoming normative in the 1570 ordo of Pius V. While that liturgy retained measures of hope, such elements as its offertory prayers and Dies irae sequence would leave "a macabre mark on the expression of faith in the face of death." 37 While the post-Vatican II Order of Christian Funerals recovered the sound tradition of a paschal, ecclesial, eschatological hope, still it could not instantly erase the popular perception of the Church's funeral rites as pessimistically focused on sin and fearful judgment. An often poor clerical comprehension and weak pastoral execution of the reformed Order of Christian Funerals, compounded by an individualistic and consumerist anthropology operative in society, leave open a ritual-symbolic void for other types of memorial to fill.

\section{Internal, Retrospective Hope: The Social-Cultural Body}

During the twentieth century a second type of meaning for death evolved in conjunction with "a consumerist outlook framed by a sense of personal freedom and individualism . . . the desire that life should be lived in as intelligible and authentic a way as possible but not necessarily in terms of established religious ideas." 38 In a veritable paradigm shift in death, modern people came to construct hope as "a retrospective fulfillment of identity of both the dead and of the bereaved" through narrative and symbolic exercises of "active memory" focusing on "their known and experienced past" of the deceased. ${ }^{39}$ For Davies the key symbol of this internal, retrospective hope is the cremated remains of the dead, whose location began migrating significantly in the 1980 s from the public, civic and ecclesial spaces of cemeteries and columbaria to private places, such as mantelpieces and backyards,

\footnotetext{
${ }^{36}$ Ibid., 24. See also Bynum, The Resurrection of the Body, 14, 113.

${ }^{37}$ Rutherford, The Death of a Christian, 60.

${ }^{38}$ Davies, A Brief History of Death, 85.

${ }^{39}$ Ibid., 122, 65.
} 
or locales personally associated with the deceased, such as a favorite recreational terrain or body of water.

The American neologism "cremains," Davies finds, signals the isolation of the bodily remains from the physical process and place of their production (crematoria, which tended to include chapel-like architecture), allowing an open-ended range of content and locations for funeral rites centered on memories of the deceased's commitments, passions, or pleasures. In 2006, the New York Times reported cremation rates at "close to 70 percent in some parts of the West." The Times article highlights the comments of a Mark Duffey, director of "the first nationwide funeral concierge service" in the United States: "The body's a downer, especially for [baby] boomers,' Mr. Duffey said. 'If the body doesn't have to be there, it frees us up to do what we want. They may want to have [the service] in a country club or bar or their favorite restaurant. That's where consumers want to go." "40 Healing, then, comes internally by making "connections" with the deceased person's lifestory, a memorial process people increasingly seek to orchestrate for themselves, with ecclesial or civic traditions playing secondary, supportive roles, if any. ${ }^{41}$

American religious historian Gary Laderman arrives at analysis similar to Davies' retrospective interpretation of modern funerals - "the role of memory images in dealing with loss" 42 _ by examining another location and disposition of the body in the twentieth century: the embalmed corpse on view in the funeral home. The modern practice of undertakers, originating in the wake of the Civil War, was by the 1920 s a nationwide industry.

The funeral home evolved into an American institution during a tumultuous period of social change: industrialization brought the "machine age" to life; consumerism introduced new relations between people and objects; and faith in science and technology undercut even further the relevance of institutional religion to everyday life. The values beginning to energize the social body in the modern era contributed greatly to the shape and texture of the American funeral, and the final appearance of the embalmed body safely cared for in the funeral home. Nevertheless, the dramatic appearance of this new home for the dead in the first half of the century became a source for much public debate and led many individuals both inside and outside the industry to scrutinize the business of burial. 43

${ }^{40}$ John Leland, "It's My Funeral and I'll Serve Ice Cream if I Want To," New York Times, July $20,2006$.

41 “' 'Baby boomers are all about being in control,' said Mr. Duffey, who started his company after running a chain of funeral homes. 'This generation wants to control everything, from the food to the words to the order of the service. And this is one area where consumers feel out of control" "(ibid.).

${ }^{42}$ Gary Laderman, Rest in Peace: A Cultural History of Death and the Funeral Home in TwentiethCentury America (New York: Oxford University Press, 2003) 23.

${ }^{43}$ Ibid., 47. 
Laderman's persuasive explanation for the successful establishment of the industry's practices includes the assessment that funeral directors were responding to what modern Americans wanted, namely, care for the deceased that was both consistent with scientific sanitary sensibilities and consonant with mourners' therapeutic need for bodily encounter with their dearly departed. That the departure (death) decreasingly took place amidst kin in one's home, due to not only medical technology but also friends and family members living at significant distances, plus a "confusion around [grief's] value in the lives of busy, hard-working Americans," 44 altogether contributed to people's need for the "last look." This ritual gesture, carried out in the funeral home, a space resembling both bedroom and front parlor, became for mourners an experience of confirming (accepting) that the deceased was indeed dead and a moment for a parting dialogue in one's imagination with the dead person. These aspects of the practice comprised what its supporters and propagators considered its therapeutic function. The "viewing," moreover, acquired the social dimension of winning honor and guarding shame. Popular culture came to judge the results of the mortician's work with the corpse, along with the extent of other amenities and services they purchased from the funeral director, as indicative of the family's care for their loved one.

Beginning in the 1930s and well into the second half of the century, however, viewing the embalmed corpse, along with other customs funeral directors had successfully established, came under repeated harsh religious, political, and classoriented criticism. Socially concerned government and religious officials accused the funeral industry of taking financial advantage of the poorer class in their times of grief, while certain Protestant and Catholic clergy also attacked morticians' efforts to achieve "that alive look" as valorizing the body to the detriment of the soul, a renewal of pagan idolatry. Congressional hearings, pastoral tracts, and exposés in news weeklies waged a power struggle with funeral directors over the bodies of the dead, with British commentator Jessica Mitford's The American Way of Death (1963) stirring up controversy and achieving big sales on the stands. Still, despite all the hype and eventual governmental regulatory actions during those decades, Laderman finds ongoing evidence for Jewish, Protestant, and Catholic clergy and local funeral directors largely building and sustaining positive working relationships. ${ }^{45}$ In addition, patriotic association of the dignified display and disposition of the fallen soldiers' body with the glory and preservation of the American social body during and after World War II solidified popular acceptance of funeral

44 Ibid., 102.

45 In the past decade the Roman Catholic Archdiocese of Los Angeles took such alliance with the funeral industry to a new level by entering into a leasing agreement with one of the largest funeral company chains in the country, allowing the corporation to build and operate mortuaries at six of its eleven cemeteries. See Leslie Wirpsa, “'Death care giants' team up with church: Relationship raises issues about church role in bereavement," National Catholic Reporter (January 30, 1998) 9-12. 
directors as providing a service representing such cultural values as "individualism, democracy, freedom, and free enterprise." 46

Granted the significant contested dimensions (economic, religious, political) of modern mortuary practice, still, it seems that Americans largely adopted and have continued to utilize these services because they have suited the therapeutic approach to individual meaning-making in modern society. Laderman summarizes the position espoused by funeral directors and supporters of the funeral industry: "This idiom framed the funeral as an instrument of psychological as well as spiritual healing for survivors, and the viewable body was defined as the active agent in the eventual triumph over the pain of losing a loved one. It was a moment to confront the reality of death, by looking in the face of the deceased without seeing the unsettling signs of decomposition, and thus begin the process of working through personal grief by creating a living memory." 47 The controversy within the professional medical, psychological, and popular debates about this "grief mythology" basically concerned whether the embalmed, cosmetically altered corpse in comfortable repose at the funeral home signals a cultural denial of death. That rhetoric, however, does appear to be misleading, for the issue would seem often to reduce not to people's denial but, rather, interpretation of death, what images and symbols provide an adequate way to integrate the negative shock of death into "a sacred context for meaning and action in everyday life." 48 Observation through the twentieth century would seem to support the conclusion that most Christians, including Roman Catholics, have found the embalmed, displayed corpse symbolically consistent with, if not reinforcing of, their beliefs (however vague) about the continued personhood of the deceased as a subject of God's good creation and Christ's resurrection. ${ }^{49}$ Whether theologians, pastors, and commentators are satisfied with popular (including Catholic) Christian understandings of the resurrection is a different question than an alleged American denial of death, a point I shall address in the concluding section.

Meanwhile, the social landscape at the turn of the twenty-first century increasingly orients around a practical, comprehensive ideology of the individual, and with that, a continued struggle for control over the ritual body of death. Now, however, the contest is not between undertakers and some clergy, government, or other watchdogs but, rather, between the century-old funeral industry and new types of

${ }^{46}$ Laderman, Rest in Peace, 80.

${ }^{47}$ Ibid., 100-101.

${ }^{48}$ Ibid., 110.

49 See ibid., 130-31, 160-61. That the practices of American undertakers, nonetheless, remains a contested issue among some of the faithful is evident, for example, in a negative review of Laderman's work published by an American Catholic magazine of opinion. See John C. Cort, "Last Wrongs," Commonweal (August 13, 2004) 31-33. 
professionals - funeral planners (a subset of the generic event planner)—aligning with the individual consumer's assertion of authority over one's memorial rites. I have already introduced this new dynamic in noting the shifting location of cremated remains from the place of the coffin in traditional rites (churches, chapels, funeral homes, cemeteries) to complete absence from funeral services. Recall funeral concierge Duffey: "If the body doesn't have to be there, it frees us up to do what we want." And what Americans want to do, increasingly, is memorialize themselves according to some activity or place that captures their personality and lifestory, whether that be along recreational lines (e.g., a service on a golf course, a concert at the local performing arts center) or a celebration of one's career. The New York Times article relays the example of an ice cream vendor who arranged for his old ice cream truck to lead his funeral procession, concluding with the doling out of popsicles. A less idiosyncratic innovation well suited to digital imagebased culture is the "tribute video," which one funeral planner describes as a "spiritual biography" anchoring the funeral service as an "experience ... where you get to really know a person." 50 Prepared and often narrated by the deceased at some point in her or his later life, the video would seem to function not so much as a memorial but as a continued exercise of the person-subject expressing something further of oneself after death.

The emergence of funeral planners and individually-tailored rituals is not only a development positively attuned to the late-modern social body but also a negative response to the keepers of the traditional body, that is, pastoral ministers in local Christian churches. A Washington Post article describes baby boomers' dissatisfaction with the generally impersonal and "sometimes stale" quality of traditional, church-based funeral services. Stepping into the void are "funeral celebrants," a concept originating in New Zealand and Australia now spreading in the United States, who testify to how "one size fits all" religious funerals are proving "less than fulfilling for many mourners and providing inadequate memorials for people who hadn't attended church regularly." 51 The desired alternative for many is an upbeat celebration of life. The sister of a deceased auto-parts manager, for example, provided this assessment of the memorial rite a funeral celebrant created, accenting the woman's awards, nicknames, and sports proclivities: "I was really, really happy that I went that route as opposed to a church service... . It really was a nice way to step back from the depression of losing my sister and smile a little bit and have

${ }^{50}$ Leland, "It's My Funeral."

${ }^{51}$ Ted Gregory, "Funeral Celebrants Say Goodbye, With a Twist," The Washington Post, June, 25, 2005. Gregory, of the Chicago Tribune, reports the approximate number of professional funeral celebrants in the United States to be $\mathbf{5 5 0}$ at the time of his writing, with a former Baptist minister operating a training and certification program since 1999. 
some happy memories." ${ }^{52}$ Laderman addresses these recent developments toward the end of his study, finding Oprah Winfrey's reported funeral plans, including Motown music and a self-prepared video eulogy, exemplary of "a widespread consumer interest in shaping funerals to embody and celebrate the life lived rather than conform to conventional traditions that suppress or limit expressive ceremonies." 53 Where, then, does this leave the traditional Christian body? Before that concluding consideration, one further development in the social itinerary-a turn to the natural-warrants attention.

\section{Earthy, Ecological Hope: The Natural Body}

In Davies' third type, hope embraces the natural, cosmic body through new funerary practices variably known as green, woodland, or natural burial. Part of an ecological-environmental worldview, the concern over death is not simply for one's own person but, rather, for the planet. Green burial refers "to the process of burying a body not in any traditional form of churchyard or civic cemetery but in a variety of contexts such as a field in which trees can be planted above graves to develop into woodland. Similarly, a body may be buried in glades to develop into woodland." 54 With the objective - at once aesthetic and ethical-being the human body's natural decay and contribution to the earth, embalming, lined coffins, concrete vaults, tombstones and statues cede to cloth shrouds or biodegradable wood or wicker caskets, with shrubs, trees, or in some cases natural fieldstones as markers. Originating in the United Kingdom during the past couple of decades and allied with the National Memorial Arboretum project, the woodland burial movement now accounts for over $10 \%$ of British interments. Since 1998 the United States has seen its first burial preserve in rural South Carolina usher in a small but growing number of green cemeteries dotting the land south and north, coast to coast. ${ }^{55}$

Davies analyzes woodland burial as countering both postmodernism and, to some extent, traditional Christianity. In contrast to the postmodern favoring of individuals' fragmented, idiosyncratic self-constructions over socially shared grand narratives, ecological consciousness is a comprehensive worldview. "Green" is proving a symbol powerful enough to encompass both life and death, with the corpse becoming one's final role in the "circle of life," nourishing the land and its creatures. While green burial need not necessarily entail rejection of Christian beliefs, Davies argues, still he finds belief in an "ecological immortality" driving this emergent

52 Ibid.

${ }^{53}$ Laderman, Rest in Peace, 184; see also 139, 151, 180.

${ }^{54}$ Davies, A Brief History of Death, 81.

${ }^{55}$ William Kates, "'Green' burials usher in the ultimate recycling," The Boston Globe, July 5 , 2006. 
practice, one that can in fact often function in place of conventional Christian understanding: "The key to the appeal of this outlook lies in a dynamic view of 'nature', of an ongoing system of which one is a part and not of some radical divide between mankind and nature ... woodland burial furnishes an authentic basis for understanding both life and death for those for whom either 'heaven' or 'memory' is an unbelievable or inadequate means of making sense of life and of death." $56 \mathrm{~A}$ middle-aged woman who with her family has adopted South Carolina's Ramsey Creek Preserve as their burial location articulates the contrast: "I like that the land is wild and always changing with time. . . Whether we like it or not, death is about change. To pretend my [recently deceased] brother is just sleeping under a mowed and manicured lawn is to deny that death is about change." 57 The brilliance in this quote, for the purposes of our present study, lies in not only the speaker's enlightening what the so-called American denial of death often entails - the denial of change-but also her implying that the traditional Christian images for deathrest, sleep, immortality - are likewise susceptible to interpretations that render them impotent for healing grief and fostering hope. To the content of the tradition, then, we turn in conclusion.

\section{Faith in the Resurrection of the Body: Tradition in Practice}

The Roman Sacramentary's first preface for Masses for the Dead (Christian Death I) proclaims, "Lord, for your faithful people life is changed, not ended." The power of these words to linger in thought and memory lies in their brevity and directness, and yet they belie millennia-long variations in how Christians have interpreted the symbol of resurrection. The preceding paragraph of the preface duly situates this belief within the paschal mystery: "In him, who rose from the dead, our hope of resurrection dawned. The sadness of death gives way to the bright promise of immortality." The prayer clearly asserts faith as a human act of hope in a divinely given promise while leaving open questions about the character and timing of believers' immortality. Prayers, of course, are not theological arguments. Still, the implications of how we understand our immortality in relation to Christ's resurrection are significant for how we face death-that of loved ones and ourselves - and carry out our lives accordingly.

The content of Christian hope is in question. Do the lines of the preface (Christian Death I) proclaim Jesus' resurrection as the source of all others, an unprecedented change in the human condition offered in hope to believers? Or

56 Davies, A Brief History of Death, 87.

57 Kates, " "Green' burials." The newspaper article does not neglect the consumer angle as well, noting the difference between average costs for a "traditional" (that is, American funeral industry) funeral and natural burials. 
might these words be heard to say that Jesus' resurrection gives hope by revealing to humans the sure destiny of their true nature? Put another way, does Christian hope in resurrection stand on God having done to Jesus something radically new for all humanity, namely, giving life after death? Or, on the contrary, does Jesus' resurrection give hope by confirming humanity's innate capacity for immortality? And what of the timing in all this? Do the dead enter into the risen condition immediately? After asserting life's being changed, not ended, the preface continues: "When the body of our earthly dwelling lies in death we gain an everlasting dwelling place in heaven." While perhaps acceptable in the function of consoling the liturgically-assembled faithful, who in the preface dialogue would have just lifted up their hearts to the Lord, the statement is biblically and theologically problematic. Biblical faith recognizes not the moment of one's bodily death but, rather, one's sacramental dying with Christ in baptism as establishing one's everlasting dwelling place. Baptism places all bềlievers, living and dead, in the eschatological tension, waiting for Christ's coming again in glory and judgment. The words of the preface, on the other hand, could imply that death causes an immediate passage from earth (and the body) to heaven.

The sort of ambiguity about the resurrection the current preface for Masses for the Dead betrays has riddled Christian belief since the earliest generations of the church.58 Paul, whom the Acts of the Apostles depicts being laughed off the Areopagus in Athens for proclaiming the resurrection of the dead (see Acts 17:32), chose his words well in exclaiming at the outset of his discussion of the topic in First Corinthians: "Listen, I will tell you a mystery!" He proceeds to explain that the baptized will not all die but be changed, not immediately but only "at the last trumpet," when "the dead will be raised imperishable, and we will be changed" (1 Cor 15:51-52). Bynum reports that Paul's metaphor for the deceased Christian body as a "bare seed" that must die in order to become something else (e.g., wheat), sown in a perishable physical state so as eventually to be raised an imperishable "spiritual" body (1 Cor 15:36-37, 42-43), governed pastoral teaching in the earliest Christian centuries. Irenaeus and Tertullian, each holding the whole person (body and soul) as the subject of salvation, asserted both continuity and change as paradoxically inherent to the radical transformation that will come in

${ }^{58}$ In the introduction to her book on early-through-medieval Christian beliefs about the resurrection of the dead, Bynum asserts that our late-modern "considerations of self and survival take the body with impassioned seriousness," concluding: "[T] $]$ he deep anxiety we feel about artificial intelligence and organ transplants, about the proper care of cadavers, about the definition of death-an anxiety revealed in the images of bodily partition and reassemblage that proliferate in our movies and pulp fiction - connects us more closely than most of us are aware to a long Western tradition of abstruse discussion of bodily resurrection" (The Resurrection of the Body, 17). 
the final resurrection. For Tertullian, human identity resides in bodily particularity, so that "[e]verything intrinsic to what we are must reappear in the resurrected body," even if no longer useful as before. ${ }^{59}$ Tertullian, Bynum argues, exploits the Pauline teaching about the corrupt becoming incorruptible to the maximum: God does not abandon the person in the repulsive demise of the flesh but, rather, makes it the fulcrum of salvation. Irenaeus likewise does not blink in the face of mortal decomposition, but sees promise for the total human person who in this life has consumed Christ's body, participation in a eucharistic mystery available to us only if kernels decompose in earth to yield something new, namely, grain for the sacred bread. ${ }^{60}$

While right through the High Middle Ages the eucharist would prove crucial to Christian confidence in the resurrection of the body, popular imagination and doctrinal explanations of the connection between the material of the sacrament and the postmortem fate of believers reflected a major turn in theological anthropology. The understanding of salvation shifted from the reassembling of each person's unique bodily parts for their further (Pauline) transformation into a heavenly body to the (philosophical Greek) immortal soul's finally attaining in heaven the perfect, changeless body whose form it always bore in potency. Whereas earlier generations embraced Paul's seed metaphor in anticipating God's radical change of each believers' bodily condition in the final resurrection, the "extraordinary bodily discipline of the ascetic movement" in the fourth century led to identifying change itself as the problem. ${ }^{61}$ Ascetics' mastery over basic needs of nutrition and procreation made their bodies symbols in this life (sacraments, we could now say) of the pure, unchanging, eternal state of the glorified bodies that Augustine would teach is the beatitude of those judged worthy of the resurrection of the dead. The Middle Ages brought a different twist to the iconic quality of saints. The faithful came to consider every part of the body as containing the sanctity of the whole person, just as every fragment of the eucharist was believed to contain the total Christ. The identification took symbolic form in a proliferation of reliquaries containing fragments of saints' bodies similar in design to eucharistic monstrances.

Bynum mounts ample evidence for how the ascendancy of the language of soul through the Middle Ages was not a rejection of the body but, rather, a somatizing of the soul. In the thirteenth century Aquinas' positing of the body's formal identity in the soul made possible an understanding of the self perduring independently

59 Tbid., 37.

${ }^{60}$ Ibid., 39. Bynum quotes Irenaeus's Against Heresies, V.2, 3. See also pertinent extracts of Against Heresies with commentary in Joanne E. McWilliam Dewart, Death and Resurrection, Message of the Fathers of the Church 22 (Wilmington: Michael Glazier, 1986) 92-99.

${ }^{61}$ Bynum, The Resurrection of the Body, 112. 
of the physical body's rotting demise, such that at the final resurrection the soul can take up whatever matter provided and conform it to its changeless, perfected self. Unlike Augustine, therefore, Aquinas did not consider the deceased's soul detained from the vision of God until it united again with the body at the last trumpet but, on the contrary, capable of the beatific vision immediately after death. Lest he contradict biblical faith in the resurrection of the body, Bynum argues, Thomas reasoned that the body the soul receives at the final resurrection is an expression of the glory the soul enjoys in its ongoing visio Dei. ${ }^{62}$ The matter, however, remained a cause for much debate. The official ecclesial resolution of the beatific vision controversy in the 1330 s defeated the claim that the individual cannot enjoy God until soul reunites with body; rather, Pope Benedict XII decreed, the souls of the just are able to do so separated from the bodies they will receive in the final resurrection. Belief in immediate judgment at death-resulting in beatific vision, eternal damnation, or temporal purgatiŏn - does not preclude all assembling at the trumpet call of Last Judgment, when the body will conform to the soul's final state. The papal bull of 1336 affirmed that souls can enter into the beatific vision whenever they attain full spiritual purification. Thus, "the doctrine of purgatory and the doctrine of resurrection were necessary to a theology in which death is decisive, prayers for the dead are effective, and self is a psychosomatic unity." 63

One can see in that papal resolution, which holds doctrinal sway in the Catholic Church to this day, content that both resonates with yet also challenges the imagination of modern and now postmodern Christians. The strong agency of individual selves, both that of the dead and that of the living whose prayers are efficacious toward them, would seem to be at home in contemporary society. Yet the notion of divine judgment implicit in the need for such prayers along with the full embrace of death's decisive character push back against an American culture largely in denial of the radical change that death so powerfully wields. To focus on the denial of change here is to recognize that ultimately the issue is, indeed, one of power. Denial of the radical change death entails is the denial of surrender, a persistence in asserting that one is and always will be in control over one's life and circumstances, a malaise in the contemporary social body in need of the healing ministrations nature and tradition afford.

To surrender one's body or that of a loved one to the earth's natural forces of change is to trust in a larger cosmic history that first and finally belongs to God. With the apostle Paul and the evangelist John, along with Irenaeus and Tertullian who reflected upon those scriptures, contemporary believers can perceive in the earthy decomposition of mortal bodies a powerfully kenotic "space" God has

\footnotetext{
62 See ibid., 265-71.

${ }^{63}$ Ibid., 282.
} 
entered so as to heal every aspect of the human condition, even its seeming demise. Those earliest Christian authors can still teach us how the natural material comprising our eucharistic food reveals the goodness of all creation and the place of our bodies' waxing and waning therein, as well as God's promise to bring about in this created order an even greater, unforeseen salvation. Christian tradition can discover a new saving, healing power in dialogue with such ecologically oriented movements as green burial by embracing the awareness that we are not strictly autonomous minds or souls merely using our bodies and this earth until no longer personally needed (or endured) ${ }^{64}$ Christian faith, rather, can grow by considering how the union of the deceased body with the cyclical life processes of the natural environment invites us to a more cosmic Christology and pneumatology, salvific surrender to the Word and Spirit through whom God creates, sustains, and ultimately will redeem all. ${ }^{65}$ Surrendering our bodies to the ecological environment which we received as a divine gift from the start, Christians can in faith embrace what Irenaeus so beautifully described as the two creative and redeeming hands of God-the Word and the Spirit-that have never let go of humanity, nor ever will. ${ }^{66}$ That faith lies in the hands of the man nailed to a cross, whom the Father has made the firstborn of a new creation through the power of the Spirit (see Rom 8:10-11, 18-30; Col 1:15-20; Rev 1:5). Christian faith heals human spirits broken by the fearsome change inherent in death by proclaiming, through word and sacrament, a hope fulfilling, indeed, exceeding all natural and social expectations, the hope founded on the divine love that conquered human death in Jesus.

To surrender to the traditional body of the crucified and risen Christ is, in Chauvet's terms, to assent in faith to a salvation made possible by the Word's surrender to the mercy of the body. For those baptized into Christ, contemporary social denial of the radical change wrought by death entails squandering the true freedom that comes in embracing the traditional body of the One who, in the astute terminology of N. T. Wright, has become the source of life after life after death. Wright underlines that phrase for its ability to convey the specific meaning of resurrection at the origins of Christianity. Since all the ancients, whether pagans,

${ }^{64}$ Compatibility of green burial with Christian doctrine would seem to parallel the Roman Catholic Church's endorsement of cremation as a viable option for the Christian corpse. The U.S. Bishops' cremation appendix for the OCF explains the viability of the practice as long as it is not undertaken as a rebuttal of Christian belief in the resurrection (as was the case for many in the fervor of postEnlightenment Europe). The positive view of cremation, on the other hand, is the recognition that all bodies naturally decay to dust and that faith trusts in God's mysterious plan to create a new bodily existence for all in the resurrection on the last day.

${ }^{65}$ See Jürgen Moltmann, The Spirit of Life: A Universal Affirmation, trans. Margaret Kohl (Minneapolis: Ausgburg Fortress, 1992) 8-10, 230-36; and id., God in Creation, trans. Margaret Kohl (Minneapolis: Augsburg Fortress, 1993) 9-13, 98-103.

${ }^{66}$ See Irenaeus, Against Heresies, V.6, 1. 
Jews, or Christians, could speak of some sort of enduring human condition directly following from bodily death, they recognized in the concept of anastasis (resurrection) a more provocative claim, namely, of a new life granted by God following the period of being dead.

Pagans denied this possibility; some Jews affirmed it as a long-term future hope; virtually all Christians claimed that it had happened to Jesus and would happen to them in the future. All of them were speaking of a new life after "life after death" in the popular sense, a fresh living embodiment following a period of death-as-a-state (during which one might or might not be "alive" in some other, non-bodily fashion). Nobody (except the Christians, in respect of Jesus) thought that this had already happened, even in isolated cases. ${ }^{67}$

Wright argues for how biblical faith in the resurrection bears compelling content for believers' hope in what lies beyond death as well as the implications of that eschatological vision for the conduct of lifê in this present age.

Knowledge of the complete ancient Jewish context is essential for grasping the New Testament's message about Jesus' resurrection. "Resurrection was never simply a way of speaking about 'life after death." "68 For the classical prophets, the concept had a metaphorical meaning bespeaking hope in God's bringing the nation of Israel back to life after destruction and exile through imagery eliding Yhwh's powers of creation and redemption. In the face of mounting evidence in the third century B.C.E. that Israel could not withstand foreign political domination, wisdom literature shifted hope to a new world, a new creation the righteous, as newly embodied persons, would inhabit by the gracious favor of God. Such belief necessarily gave rise to varied conceptions of the intermediate state of the dead until the eschatological dawn of the new cosmic order. The key to understanding the meaning of resurrection in second-temple Judaism, Wright argues, lies in its ranging between the metaphorical expression of the socio-political restoration of Israel and the literal re-embodiment of the righteous, living and deceased, as the new people of God. The latter was the hope of those Jews who struggled against foreign contamination, collaboration, and corruption to the point of martyrdom, as well as all who by the first century C.E. yearned for Yhwh's deliverance of a new order inhabited by a people recreated. While Herodians, Sadducees, and others collaborating with the Romans could not but be opposed to such rhetoric of resurrection, even scribes, Pharisees, or various revolutionaries committed to the concept could not imagine its happening bodily to just one person in advance of others. Thus, Wright argues, the resurrection of Jesus is both native to its second-temple Jewish milieu

${ }^{67}$ N. T. Wright, The Resurrection of the Son of God, Christian Origins and the Question of God, vol. 3 (Minneapolis: Fortress Press, 2003) 31.

${ }^{68}$ Ibid., 201. 
and startlingly original in its claim of his unique status as the risen one, source and promise of future resurrection for the people of the new covenant God has established in him.

Primordial Christian belief in the bodily resurrection of Jesus, far from focusing faith on a Christ merely removed to some distant heaven, was (and is for us now) a far more radical worldview committed to social orders and personal lives based on his lordship. Thus was the "symbolic world of early Christianity focused upon Jesus himself. The symbolic actions of baptism and eucharist, though of course having Jewish antecedents and pagan analogues, were consciously undertaken with reference to him." 69 For Christians now, history, that most fundamental of human constructions, orients itself to the risen Christ as a time of overlapping ages, the present order and the future "fresh act of creative grace when Jesus appears," when bodies, although "prone to suffering and decay," will be restored in the "full and final redemption of the creation, and ourselves within it."70 The latter is what Wright means by life after life after death. In the interim the deceased continue existence in a state biblically and traditionally characterized as rest or sleep.

I return then, finally, to the metaphorical, symbolic language of the current Order of Christian Funerals, in which confident petitioning of rest, sleep, refreshment, and peace abounds, as in this typical conclusion that follows on the assembly's praying of the Our Father:

Into your hands, O Lord, we humbly entrust our brother/sister $\mathrm{N}$.

In this life you embraced him/her with your tender love;

deliver him/her now from every evil

and bid him/her enter eternal rest. ${ }^{71}$

The presiding celebrant's introduction to the general intercessions in the funeral mass proclaims the source of hope for mourners and elicits their faith in him: "Brothers and sisters, Jesus Christ is risen from the dead and sits at the right hand of the Father, where he intercedes for his Church. Confident that God hears the voices of those who trust in the Lord Jesus, we join our prayers to his." 72 The ensuing

69 Ibid., 580.

${ }^{70}$ Ibid., 581. Douglas B. Farrow argues convincingly for how the doctrine of Jesus' bodily ascension places the lives of the baptized in the ongoing course of "Jesus history," utterly dependent upon the Spirit who makes the absent Christ present in ethical and liturgical lives patterned on his own. Recovery of the doctrine, Farrow also demonstrates, can help ward off the twin evils of clericalism and triumphalism that have so long plagued the church. See Ascension and Ecclesia: On the Significance of the Doctrine of the Ascension for Ecclesiology and Christian Cosmology (Grand Rapids, Mich.: Eerdmans, 1999).

71 OCF, no. 117-B.

${ }^{72}$ Ibid., no. 167-A. 
petitions speak of the deceased's baptism that dispelled all darkness, participation in the eucharist that leads toward the heavenly banquet, friends and family who have died and gone before, concern for those in this world now suffering injustice and death by violence, war, and famine, the family and loved ones of the deceased in need of healing from their pain and grief and, finally, all the assembled that they may live according to hope in the resurrection. Such are the words with which the faithful pray in the presence of their beloved dead, intercessions raising up not only the deceased and the assembly but all creation into the healing hands of God.

Argument and explanation are not the order of the moment but, rather, bodily performance of ritual gestures that proclaim the content of a faith lived in between the times of this age and the new creation to come and phrases evoking a hope that heals when faith feels stuck in between. Consistently powerful in my pastoralliturgical experience are those comprising the general intercessions at the vigil: "Risen Lord, pattern of our life forever .... Promise and image of what we shall be ... Son of God who came to destroy sin and death ... Word of God who delivered us from fear of death . . . Crucified Lord, forsaken in death, raised in glory. ..."73 To each invocation in that litany all respond, "Lord, have mercy," bespeaking at once the need of mourning hearts and confidence of faithful souls assembled as one body in the crucified and risen Christ, whom the presiding minister addresses in a concluding prayer, "You alone are the Holy One, you are mercy itself." 74

The church's central liturgical action is at the font and the table, baptism and eucharist, and both of these in conjunction with the proclaimed word. These frame and animate the Order of Christian Funerals. Only by them can one make sense of what we do as a church, as well as what our hope is as a church, in the face of death. Our not skirting the margins, allowing our faith to face the harsh reality of human death, not papering it over or whisking it aside, not shying from prophetic parables and sometimes stark symbols, enables us to enter into and be consoled-if not in the moment then over time-in the paradox of the paschal mystery. For if we recover this belief in God's love for all creation unto death, recover it in a way that is practical for lives of faith, then we recover as well the patristic wisdom that the glory of God is the sanctification and salvation of people. God's graciousness answers the greatest of human need. God's powerful love is known in humans' living response to that grace. The paradox emerges in God's keeping of time, which is not ours, while the glory resides in an ethics, a way of life, practiced in eschatological hope that, in most sound tradition, characterize the entire Christian life, including death, as the worship of God.

73 Ibid, no. 78.

${ }^{74}$ Ibid., no. 80-A. 